\title{
AIRPORT DISASTER MANAGEMENT PLAN TOWARDS NATURAL DISASTER
}

\author{
Muhamad Agil Saputra ${ }^{1,}$ Ready Satrio $\mathbf{A}^{2,}$ Veronica $^{3}$ \\ 1. STMT Trisakti, 2. STMT Trisakti, 3. STMT Trisakti \\ $\triangle$ corresponding author: agilsaputra44@gmail.com
}

\begin{abstract}
This paper outlines the Airport Disaster Management Plan towards the unexpected natural disaster. Mount Agung eruption issue has distracted the passengers to visit Bali as the world's tourist attraction. I Gusti Ngurah Rai International Airport as the air gateway to Bali should prepare for the pre-in-post of this natural disaster. In this paper, we propose the holistic steps as the best practices related to the Airport Disaster Management Plan mixed with several kinds of literature study of the former experts, as well as deliver the actual condition of the airport during the Mount Agung eruption issue. We use primary data from interview with the airport experts and secondary data from airport reports related to this Mount Agung eruption issue. Then, we assemble them into one discussion with descriptive approach. Many resources such as available stakeholders in the business and government resources can be utilized when a disaster occurs to achieve an agile and resilient airport operation during a natural disaster. This paper gathers that the understanding and eloquent management of such events could be vastly improved through the implementation of Airport Emergency Plan through Airport Disaster Management Plan when facing a specific disaster.

Keyword: Airport Disaster Management Plan, Airport Emergency Plan, Natural Disaster, Pre-Disaster, Post Disaster
\end{abstract}

\section{Introduction}

Natural disaster happens unpredictably every year, claiming thousands of casualties around the world. Described by Martono \& Marina, 2016 Indonesia is an archipelagic country with more than 17,500 islands. Airspace spanning $5,500 \mathrm{~km}$ from west to east and 2,430 km from south to north. Because of its geographical area, Indonesia has a high probability towards unexpected natural disaster. By this fact, Indonesian airports should be ready to face it. Directorate General of Civil Aviation Regulation, No. 378 of 2011 Article No.2 states that every party that operates airport should make an Airport Emergency Plan based on the guidance from Advisory Circular CASR Part 139-16. This regulation was written by the guidance from ICAO (International Civil Aviation Organization) Annex 14 Volume I "Aerodrome” and Doc. 9137- AN/898, Part 7 about Airport Emergency Plan. Airport Emergency Plan consists of several chapters. One of them is Airport Disaster 
Management Plan that is needed by every airport to handle a specific disaster. Based on (Kunz, Reiner, \& Gold, 2013), IFRC (International Federation of Red Cross and Red Crescent) defines disaster as a unexpected and devastating event that disrupts the functioning of people in a country or a society and impacts human, material, and economic or environmental losses that outdo the society's ability to cope using its own resources. Disaster management is defined as a series of interrelated activities, including processes related to impact, response, recovery, development, prevention, mitigation and preparedness (Carter, 1991). Many experts argue that a lot of investigations should be accomplished to determine the management model to come out with the viable impact when preparing for, reacting to, and recovering from a disaster or an emergency event and it also needs to establish the effects of planning on preparedness (AlBattat \& MatSom, 2014; Drabek, 1995). Currently, I Gusti Ngurah Rai International Airport Bali-Indonesia faced an issue of the eruption of Mount Agung in Karang Asem District, Bali. Stated by (Agushinta \& Wiratama, 2016) due to development of traffic of passengers, goods, cargos and posts, airport should do a research and development to keep maintaining the performance of airport in every situation for all customer safety and security. Indonesia faces the high probability of volcanic mountain. Noted by BMKG, there are 8 volcanic issues in 20162017. Although the Airport and Mount Agung are $70 \mathrm{KM}$ apart, the effects of the eruption will directly cause damage to the airport facilities and operational activities. By facing this issue, passengers will be aware before visiting some places in Bali. Based on this fact, this paper delivers the Airport Disaster Management Plan of I Gusti Ngurah Rai International Airport towards Mount Agung eruption issue.

\section{Method}

In this research, we use descriptive analysis method to describe more specifically about the problem. Goodman \& Calderon, 2012 state that descriptive research includes the describing, recording, analyzing and interpreting the present nature, processes of the phenomena or event which 
focus on persuading conditions or how a person or community behaves. It usually involves some types of comparison or contrast depend on the approach writer uses. It is also defined as an intentionally process of gathering, classifying, analyzing and concluding data about current conditions, phenomena, trends and cause-effect relations or other related relation and then making an accurate interpretation about the data with or without the tools of statistical methods. It is also supported in Simarmata \& Keke, 2017 states that descriptive research is the methodology for studying the condition of a current human being situation, a way of thinking, or a phenomenon in several timeline aimed to make description in factual and high accuracy. The descriptive method is something more and beyond just data gathering, it includes the continuous understanding in several perspectives. In this paper, we use some of collecting data methods from former literature studies, interview with the airport experts, and also reports from the airport. This collecting data method is supported with direct observation in the Emergency Operation Centre in I Gusti Ngurah Rai International Airport that we did from September to October 2017.

\section{Discussion and Result}

The response to a natural disaster generally requires all sides assistance that may born from several related parties. However, it often comes from succor organizations, which have the capacities, capabilities, knowledges and most needed resources to help the casualties in crisis. Due to the current demographic growth, migration movements, and climatic shifts, there is strong evidence that the frequency and effects of disasters will increase (Clay Whybark, 2007). The latest years have seen a considerable augmentation in the number, scope and complexity of disasters. By this fact, planning is such a process and the updated plans should be tested and evaluated through a form of test and evaluation (AlBattat \& MatSom, 2014). Helsloot \& Ruitenberg, 2004 defines that the minor difference between planning and preparedness comes from the practice. Planning should be the standard of preparedness. Alexander, 2003 also defines the emergency planning as an organized set of 
procedures for managing an emergency event, whether expected or not, whenever it takes. Every emergency has its own signature, but with enough similarity between them, it will be easier to make predictions, warning for related parties , and planning for government (Alexander, 2011). I Gusti Ngurah Rai Airport Bali, in collaboration with BMKG (Indonesian Agency for Meteorological, Climatological and Geophysics), always updates the condition of Mount Agung. Therefore, the updated condition is highly important to take the attention to the preparedness and the planning, countermeasure and recovery process (Alexander, 2011). Mount Agung eruption will produce volcanic ash. Volcanic ash from the mountain will disturb the operation of aircraft in the air and at the airport. When the volcanic ash is spreading and entering airport scope, the airport should be closed in order to keep the safety of the airport operational activities.

Table 1. Disaster Life Cycle Models (Ritchie, 2004)

\begin{tabular}{|c|c|c|}
\hline \multicolumn{1}{|c|}{ Author } & Type of Disaster & Content of the model \\
\hline (Faulkner, 2001) & Natural Disaster (Flood) & $\begin{array}{c}\text { Pre-Event, Prodormal, Emergency, } \\
\text { Intermediate, Long-term (Recovery) and } \\
\text { Resolution }\end{array}$ \\
\hline (Roberts, 1994) & Natural Disaster (Flood) & $\begin{array}{c}\text { Pre-event Phase, Emergency Phase, } \\
\text { Intermediate Phase and Long-term Phase } \\
\text { (Recovery) }\end{array}$ \\
\hline (Fink, 1986) & General & $\begin{array}{c}\text { Prodormal Stage, Acute Stage, Chronic } \\
\text { Stage (Recovery) and Resolution Stage }\end{array}$ \\
\hline
\end{tabular}

In explaining this problem, a former literature study by (Faulkner, 2001; Fink, 1986; Roberts, 1994) mentions that in every disaster, there would be disaster life cycle. These disaster life cycle models are a cycle of disaster from the start to the end of disaster. In their papers, they explain each of disaster life cycle and its treatments. Related to these previous theories, there are 4 phases stated by Director Regulation of PT Angkasa Pura I (Persero) Number: 170/OB.30/2015. In this regulation, Airport Disaster Management Plan named it as Phases of Crisis Management. This phase of crisis consists of: 


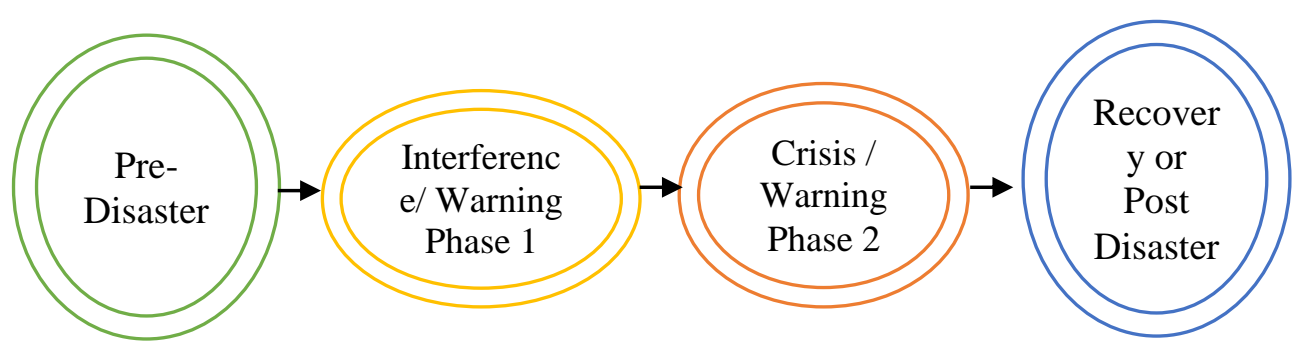

Figure 1. Phases of Crisis Managemen

Pre-Disaster means all earlier preparation for facing an upcoming disaster. Hany Abulnour, 2014 describes that this Pre-Disaster phase includes all of the activities that prepare the related parties to encounter disaster. These pre-disaster activities include the organization, improvement of procedures, inventory of resources and establishment of response plans based on Airport Disaster Management Plan statement. The activities attributed to this phase can be sub-classified into the three phases of disaster prevention, mitigation and preparedness. It was started on September, $22^{\text {nd }} 2017$ until October $15^{\text {th }}$ 2017, Airport countermeasure for Mount Agung Eruption was still in the form of coordination with the related stakeholders through internal and external meetings. To monitor and to watch the condition of Mount Agung, the airport prepared to open the EOC (Emergency Operation Control). As stated by Rahmat Yoni Saputra (Personal Communication, October $4^{\text {th }} 2017$ ) as the Airport Operation Terminal and Landside Section Head, there are 5 parties involved in this EOC. There are delegations from AVSEC or Aviation Security, ARFF or Airport Rescue and Fire Fighter, AMC or Apron Movement Control, Terminal Inspector, and BMKG who did a comprehensive coordination with PVMBG or Pusat Vulkanologi dan Mitigasi Bencana Geologi (Centre of Volcanology and Geology Disaster).

Interference Phase or Warning Phase $\mathbf{1}$ is a phase when the situation from pre-alert phase is showing a higher risky hazard than the pre-disaster situation. It started on September, 22 $2^{\text {th }}$ 2017, the status of Mount Agung was in Level IV (Awas/Watch out). Hany Abulnour, 2014, states that hazards can be monitored before they evolve into disasters. Scientific indicators can 
predict or forecast a disaster event including its magnitude. By the airport historical data in 2015, the airport was impacted by Mount Raung eruption until the temporary airport closure for 4 hours. This situation happened because of the volcanic ash entering the aerodrome and it may disturb the operation of aircraft. It is thus deducible that the warning phase should precede a disaster situation but should also be simultaneous to the occurrence of the disaster. In other words, a warning should be executed when a disaster event is forecasted as well as while the primary indicators are signifying that a disaster event is occurring. In this warning phase, Airport Disaster Management Plan plans interference phase or warning phase 1 with 4 subclassified preparations, namely:

1. Preparing Airport Disaster Form

Passenger Registration Form is used in handling the passenger facilitation onward to their destination. The passengers should fulfil this form that consists of the date of disaster, name, the date of birth, their contact number, the airline use, the flight number, and the choice. This fulfilment ends with approval from airline and airport officer. It also represents the acceptance and approval for their alternative journey.

2. Handling passenger

Passengers are the priority in an emergency situation. In the airport, most of the passengers are located in 3 areas; they are check-in area, waiting room and baggage claim area. Every passenger in those 3 areas should report himself or herself to the designated officer to fill in the officer data. The passenger should stay in their location until further notice.

3. Flow Chart and site plan of handling passengers and luggage The last sub-classified of this phase is Flow of Passenger movement for evacuation. This flow shows the path or flow of passengers and where passengers should go. The flow states as follow: 


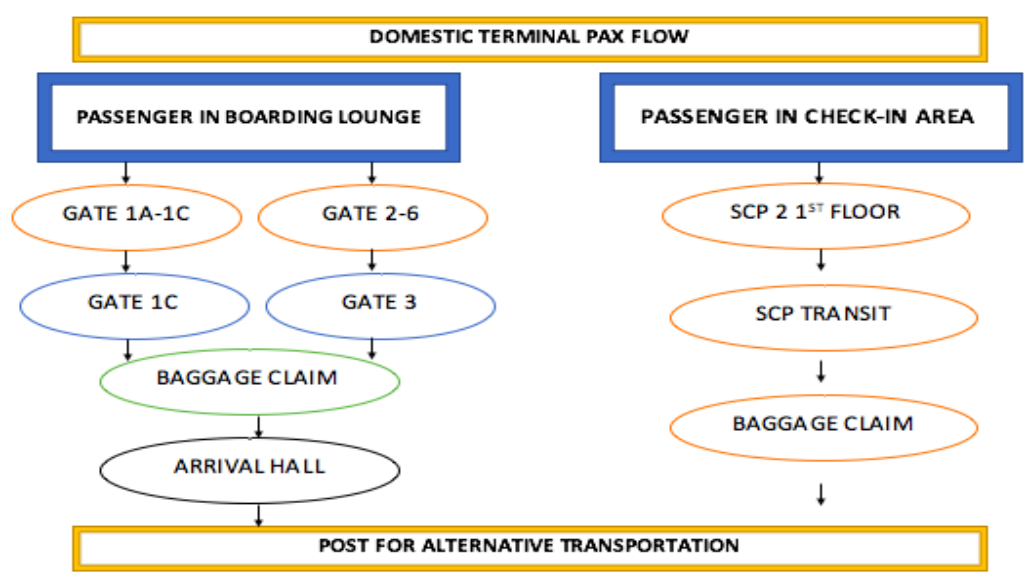

Figure 2. Domestic Terminal-Pax Flow

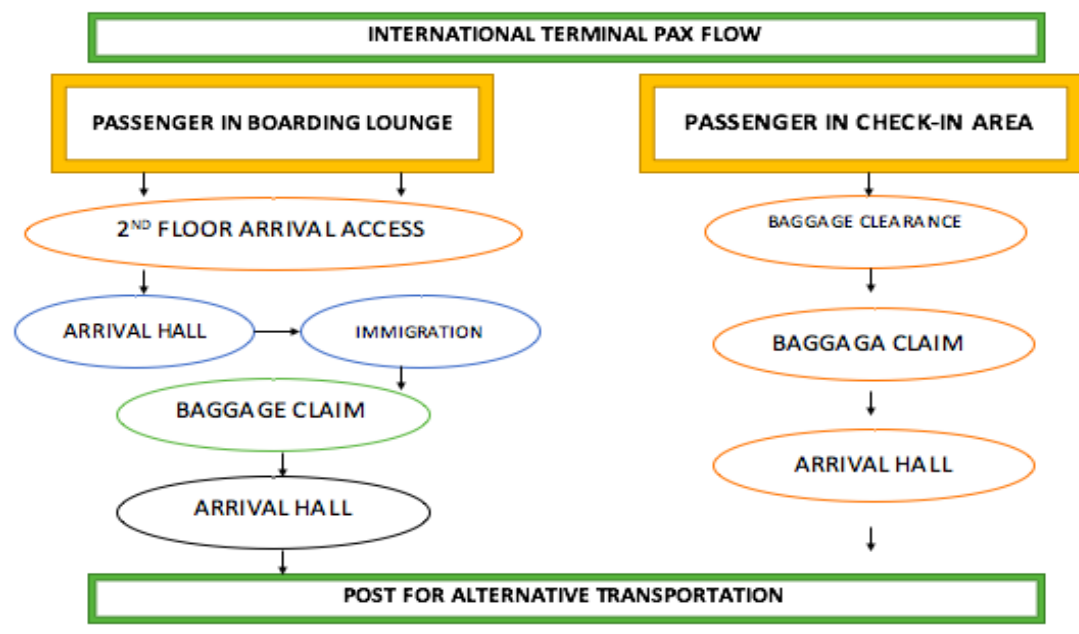

Figure 3. International Terminal-Pax Flow

4. Facilities and other supporting preparation

Airport is a territory of runways and buildings for the take-off, landing, and MRO (maintenance, repair and overhaul) of aircraft, with some facilitations for passengers. Airport revenue is dedicated to improving the facility to passengers when entering the airport to go to their destination by aircraft. A study by (Halpern, Graham, \& Davidson, 2012), Airport location can be promoted as a source of profitable and usable for passenger (whether or not the facilities themselves are directly run by the airport operator or are actually within the airport), this may increase the overall incoming income of the airport and help it becomes more 
competitive and profitable in both attracting airlines and their passengers, including the airport facilities during an emergency situation. First of all is the Post. This post is a special post to handle the passenger during an emergency situation. Second of all is Airport officers in EOC who keep updating the related situation. Next is Gathering Point as a point to gather all casualties within the airport. Then, Media is one of the most important things to be considered as the medium to transfer information quickly. As studied by Jacobs \& Wonneberger, 2017, studies on reciprocal effects of media coverage show that subjects of media coverage can be affected by media messages about them. This call center handled by customer service officer to receive the call from all parties that need any information about the updated condition. Lastly, prepare an alternative transportation by Land transportation through Mengwi Bus Terminal and by Sea Transportation to Gilimanuk seaport or Benoa seaport. Every movement within the airport is also regulated by newest internal parking policy to free the parking fee and designated parking place.

Crisis or Warning Phase II. The objective is to find ways to make emergency plans more resilient since Mount Agung will give direct impact to the airport such as smoke and volcanic ash that is carried by the smoke, considering the Mount Agung eruption in 1963 that impacted greater area up until Surabaya city. In this phase, to ease the passenger movement, the sitemap of the Airport is declared and informed to all passengers that need help for their safety, security, or for their flight certainty. In this phase, we can conclude the action point from what we prepared in the previous phase (Interference or Warning Phase I). This implementation will be supported by the post location to handle the passengers. Post location in domestic terminal is located outside the terminal building near arrival hall. This location eases passenger to access alternative transportation given by the officers. Meanwhile, International terminal location is located on the west side of the airport. The International terminal consists of 3 floors. The first floor is for arrival, the second floor is for airline offices, and the third floor is for departure. The emergency post in this terminal is located on the second floor 
of the terminal. This location will ease passenger, airport operator and airline to do the coordination effectively. Stated by Kania, n.d., the current process should involve in develop a total safety need to be supported from all line. It is beyond the employee participation. It is all about the airport, airline, and related parties' commitment and empowerment towards this disaster to be handled smoothly.

Recovery or Post-Disaster phase. In this last phase, the remaining disaster condition is decreasing and does not give any impact to the airport operational activities. This phase is started when BMKG declares the status is safe and airport officers in EOC declares the safety to do an operation of aircraft within the airport. ARFF also does a direct checking towards all parts of the aerodrome for the existence of volcanic ash or other object and obstacle that disturb the operation of aircraft. This stage is also explained by AlBattat $\&$ MatSom, 2014. This recovery phase gives a tremendous chance to explore and to improve the capacity of local organizations and related parties to facilitate all related sectors for a certain time after the disaster. He also argues that recovery from a disaster could offer large amount of benefits to the organization such as minimizing costs related on impact of the disaster, increasing effectiveness of airport operation, updating policies by evaluate the trend of the disaster, and reducing future risk vulnerability, by amending the physical improvement and strengthen the mitigation immediately. Besides, communication and publication is the main excitement for this phase. Ritchie, 2004 states that quick response and treatment to demands of the media communication (conventional or electronic) is important as the media needs the updated information for their production feeds. Zerman, 1995, agrees by stating that the all medias have the power to make an impact in business. In addition, Hall, 2002 notes that the medias, through the actual and attractive issues, can bring issues to the attention of government and policymakers because of the power effect and influence they have, and in fact can help exceed the recovery process. Interpersonal communication between all related parties will give maximum performance of service quality during disaster (Thamrin, 2016). 


\section{Conclusion}

Every passenger in aviation industry must be aware of the safety and security of their flight or the place that they will visit. Given the actual data, natural disaster issue will give a big impact for the passengers to cancel or reschedule their planning to their destination, including Bali as the one of favorite destinations in the world. From an operator's point of view, I Gusti Ngurah Rai Airport has its own Airport Disaster Management Plan that is stated in Airport Emergency Planning. This Airport Disaster Management Plan is complete and applicable for Airport preparation towards the Mount Agung eruption issue. Through this Airport Disaster Management Plan, there are 4 major phases in this Disaster management plan to encounter Mount Agung eruption issue. There are Pre-Disaster phase, Interference or Warning Phase 1, Crisis or Warning phase 2, and Post-Disaster or recovery. Every phase has its own treatments. These treatments will give advantages to all parties because each of them will give direct and indirect actions for all officer to serve the passenger at the airport before and after the disaster. In passenger point of view, this update of regulation will give a direct therapy for the passenger to feel safe and secure when coming to Indonesia especially to Bali through I Gusti Ngurah Rai International Airport during this natural disaster issue. A natural disaster is an unexpected event, but, the airport has its own plan to face this situation and keeps the operation normally smooth as silk.

\section{References}

Agushinta, L., \& Wiratama, A. (2016). Pelayanan Fasilitas Terminal Bagi Pengguna Jasa Penerbangan. Jurnal Manajemen Bisnis Transportasi Dan Logistik, Vol 2, 267-275.

AlBattat, A. R., \& MatSom, A. P. (2014). Emergency Planning and Disaster Recovery in Malaysian Hospitality Industry. Procedia - Social and Behavioral Sciences, 144, 45-53. https://doi.org/10.1016/j.sbspro.2014.07.272

Alexander, D. (2003). Towards the development of standards in emergency management training and education. Disaster Prevention and Management: An International Journal, 12(2), 113-123. https://doi.org/10.1108/09653560310474223

Alexander, D. (2011). Principles of emergency planning and management. Carter, N. W. (1991). Disaster management: A disaster manager's handbook. 
Asian Development Bank.

Clay Whybark, D. (2007). Issues in managing disaster relief inventories. International Journal of Production Economics, 108(1-2), 228-235. https://doi.org/10.1016/j.ijpe.2006.12.012

Drabek, T. E. (1995). from the SAGE Social Science Collections . All Rights Reserved ., 86-96.

Faulkner, B. (2001). Towards a framework for tourism disaster management. Tourism Management, 22(2), 135-147. https://doi.org/10.1016/S02615177(00)00048-0

Fink, S. (1986). Crisis Management: Planning for the Inevitable.

Goodman, R., \& Calderon, A. (2012). The Use of Mindfulness in Trauma Counseling. Journal of Mental Health Counseling, 34(3), 254-268. https://doi.org/10.17744/mehc.34.3.930020422n168322

Hall, C. M. (2002). Travel Safety, Terrorism and the Media: The Significance of the Issue-Attention Cycle. Current Issues in Tourism, 5(5), 458-466. https://doi.org/10.1080/13683500208667935

Halpern, N., Graham, A., \& Davidson, R. (2012). Journal of Air Transport Management Meetings facilities at airports. Journal of Air Transport Management, 18(1), 54-58. https://doi.org/10.1016/j.jairtraman.2011.09.001

Hany Abulnour, A. (2014). Towards efficient disaster management in Egypt. HBRC Journal, 10(2), 117-126. https://doi.org/10.1016/j.hbrcj.2013.07.004

Helsloot, I., \& Ruitenberg, A. (2004). Citizen response to disaters: A survey of literature and some practical implications. Journal of Contingencies and Crisis Management, 12(3), 98-111. https://doi.org/10.1111/j.09660879.2004.00440.x

Jacobs, S., \& Wonneberger, A. (2017). Did we make it to the news? Effects of actual and perceived media coverage on media orientations of communication professionals. Public Relations Review, 43(3), 547-559. https://doi.org/10.1016/j.pubrev.2017.03.010

Kania, D. D. (2016). Analisis Faktor Budaya Keselamatan dan Kesehatan Kerja ( K3 ) Pada Penanganan Kargo Di Bandara Soekarno Hatta International Airport. Jurnal Manajemen Transportasi Dan Logistik, $3(1), 1-13$.

Kunz, N., Reiner, G., \& Gold, S. (2013). Int . J . Production Economics Investing in disaster management capabilities versus pre-positioning inventory: A new approach to disaster preparedness. Intern. Journal of Production Economics, 1-12. https://doi.org/10.1016/j.ijpe.2013.11.002

Martono, K., \& Marina, S. (2016). Domestic Air Transport Regulations in Indonesia. Jurnal Manajemen Transportasi Dan Logistik, 3(1), 1-19.

Ritchie, B. W. (2004). Chaos, crises and disasters: A strategic approach to crisis management in the tourism industry. Tourism Management, 25(6), 669-683. https://doi.org/10.1016/j.tourman.2003.09.004

Roberts, V. (1994). Flood Management: Bradford Paper. Disaster Prevention and Management, 3(2), 44-60. https://doi.org/10.1108/09653569410053932 
Simarmata, J., \& Keke, Y. (2017). The Influence of Travel Agent , Infrastructure and Accommodation on Tourist Satisfaction, 28(Ictgtd 2016), 281-283.

Thamrin, M. (2016). KUALITAS PELAYANAN JASA KEAGENAN KAPAL DAN KOMUNIKASI INTERPERSONAL PADA SERVICES QUALITY OF SHIP AGENCY SERVICES AND INTERPERSONAL COMMUNICATION IN SHIPPING COMPANIES. Jurnal Manajemen Transportasi Dan Logistik, 3(2), 217-225.

Zerman, D. (1995). Crisis communication: managing the mass media. Information Management \& Computer Security, 3(5), 25-28. https://doi.org/10.1108/09685229510793013 